\title{
Trichosporon inkin meningitis in Northeast Brazil: first case report and review of the literature
}

\author{
Eveline Pipolo Milan', Walicyranison Plinio Silva-Rocha², Jéssica Jacinto Salviano de Almeida1, \\ Tatiane Uetti Gomes Fernandes' ${ }^{1}$ André Luciano de Araújo Prudente ${ }^{1}$, Matheus Firmino de Azevedo², \\ Elaine Cristina Francisco ${ }^{3}$, Analy Salles de Azevedo Melo ${ }^{3}$, Arnaldo Lopes Colombo ${ }^{3}$ \\ and Guilherme Maranhão Chaves ${ }^{2^{*}}$
}

\begin{abstract}
Background: Trichosporon species may colonize the skin, respiratory tract and gastrointestinal tract of human beings. The yeast is recognized as etiological agent of white piedra, a superficial mycosis. Nevertheless, immunocompromised hosts may develop invasive Trichosporonosis. Central nervous system trichosporonosis is a very rare clinical manifestation. In fact, only a few cases have been published in the literature and none of them was caused by Trichosporon inkin.

Case presentation: Here we report the first clinical case of meningoencephalitis due to this species in a female previously healthy patient under corticosteroids and antibiotics therapy for several months. She was submitted to an invasive procedure to remove a left sided acoustic neuroma and further developed a cerebrospinal fistula. After some days of the procedure, she presented a predominantly and intensive occipital holocranial headache, followed by vomiting, hyporexia, weight loss, asthenia, irritability, difficulty to concentrate and rotator vertigo. The patient further developed a cerebrospinal fistula in the occipital region and was submitted to a surgical correction. After several months of clinical interventions, she was diagnosed with CNS Trichosporonosis, after Magnetic Resonance Imaging and positive microbiological cultures obtained within two different occasions (2 weeks apart). Despite the antifungal therapy with Amphotericin B and Voriconazole, the patient did not survive.

Conclusions: Despite CNS Fungal infections are mostly due to Cryptococcus spp., other emergent yeasts, such as T. inkin may be considered as a likely etiological agent. This is the first case report of CNS Trichosporonosis, where species identification was performed with rDNA sequencing.
\end{abstract}

Keywords: Invasive Trichosporonosis, Meningoencephalitis, Trichosporon inkin, Virulence factors, Antifungal susceptibility testing, Northeast Brazil

\section{Background}

Trichosporon species are basidiomycetous yeast-like fungi widely distributed in nature, predominantly found in tropical and temperate areas [1]. Trichosporon spp. may be found in substrates such as soil, decomposing wood, air, rivers, lakes, seawater, cheese, scarab beetles, bird

\footnotetext{
* Correspondence: guilherme.chaves@ufrnet.br

${ }^{2}$ Centro de Ciências da Saúde, Laboratório de Micologia Médica e Molecular, Departamento de Análises Clínicas e Toxicológicas, Universidade Federal do Rio Grande do Norte, Rua Gal. Gustavo Cordeiro de Faria S/N, Petrópolis, Natal, Rio Grande do Norte, Brazil

Full list of author information is available at the end of the article
}

droppings, bats, pigeons and cattle [1]. These organisms also are present in the human microbiota of skin and gastrointestinal tract [2]. Trichosporon spp. are phenotypically characterized by colonies of white or cream coloring, with dry appearance, cerebriform or radiated surface [3] and microscopically by the presence of blastoconidia, arthroconidia, pseudophyphae and true hyphae [4].

Trichosporon spp. are usually associated with superficial mycosis such as white piedra $[1,4,5]$, onychomycosis $[1,5-7]$ interdigital and inguinocrural lesions $[5,7]$. Invasive trichosporonosis is a deep-seated infection which

(c) The Author(s). 2018 Open Access This article is distributed under the terms of the Creative Commons Attribution 4.0 International License (http://creativecommons.org/licenses/by/4.0/), which permits unrestricted use, distribution, and reproduction in any medium, provided you give appropriate credit to the original author(s) and the source, provide a link to the Creative Commons license, and indicate if changes were made. The Creative Commons Public Domain Dedication waiver (http://creativecommons.org/publicdomain/zero/1.0/) applies to the data made available in this article, unless otherwise stated. 
may be observed in leukemia or lymphoma patients who developed severe neutropenia, associated with broad spectrum antibiotic therapy [2, 4]. Trichosporon asahii and $T$. mucoides are the most frequently isolated species in invasive trichosporonosis $[4,8]$. Pubmed searches using the terms "Trichosporon inkin", "invasive" and "infection" only retrieved six publications [9-14].

The establishment of fungal infection is associated with host immune conditions as well as virulence attributes of the microorganism involved. For instance, adhesion to epithelial cells [15], the production and secretion of hydrolytic enzymes such as phospholipases and hemolysins [16] and the capacity of biofilm formation [17] contribute to yeasts pathogenicity and have been demonstrated in Trichosporon spp.

Central nervous system (CNS) trichosporonosis is a rare clinical manifestation associated with immunocompromised patients [18]. In fact, only a few clinical cases of this medical condition have been reported in the literature $[2,4$, 18-25] and none of them was due to T. inkin.

The gold standard diagnosis of CNS trichosporonosis is the isolation of Trichosporon in culture of tissue samples or cerebrospinal fluid (CSF) $[1,19]$. The reference method for Trichosporon species identification is based on Intergenic Spacer 1 (IGS1) region of the ribosomal DNA sequencing $[8,26]$. However, Matrix-Assisted Laser Desorption/ Ionization Time-of-Flight (MALDI-TOF) Mass Spectrometry has been shown to be a valuable alternative to Trichosporon species identification $[1,27]$.

Despite some controversies, triazoles appear to be the best first line antifungal therapy for invasive trichosporonosis, especially when $T$. asahii is involved [1, 10, 18, 19, 27]. In vitro studies suggest that voriconazole exhibits the best antifungal activity against different Trichosporon species, when compared to amphotericin B and fluconazole [10]. Echinocandins are associated with high MIC values [19, 28] and indicates no action on Trichosporon cells. Therefore, they are not indicated in clinical practice $[19,27]$.

To the best of our knowledge, we describe the first case of meningoencephalitis due to T. inkin in a previously healthy female patient under corticosteroids regimen after having undergonea microsurgery of neuroma in Natal, Rio Grande do Norte State, Northeast Brazil. We also describe theantifungal susceptibility profiling and characterization of the expression of virulence factors in vitro of two $T$. inkin isolates sequentially obtained from the CSF of this patient and also a review of meningoencephalitis clinical cases due to Trichosporon spp. reported in the literature.

\section{Case presentation}

MECM, a 49-years-old previously healthy woman, married and childless, was admitted at a private hospital in Natal City, Rio Grande do Norte State, Brazil, in June, 2014 for a microsurgery of neuroma. She used to live in a flat with a parrot who had an unknown disease that caused loss of feathers. The microsurgery was performed via the cranial middle fossa to remove a left sided acoustic neuroma. After 40 days of the procedure, she presented a predominantly and intensive occipital holocranial headache, followed by vomiting. She was managed with analgesia and prednisone $20 \mathrm{mg} /$ day for 5 days. The patient also had hyporexia that was accentuated with the worsening of headache, $12 \mathrm{~kg}$ of weight loss, asthenia, irritability, difficulty to concentrate and rotator vertigo. She did not have a fever. On physical examination, the patient presented classic signs of irritability of meningeal inflammation.

On the 50th postoperative day, she was diagnosed with a cerebrospinal fistula in the occipital region and submitted to a surgical correction. The CSF analysis revealed 126 cells $/ \mathrm{mm}^{3}$, composed by $63 \%$ of lymphomonocytes, $13 \mathrm{mg} / \mathrm{dl}$ of glucose levels $(89 \mathrm{mg} / \mathrm{dl}$ of glycemia) and $189 \mathrm{mg} / \mathrm{dL}$ of proteins. Direct examination and CSF microbiological culturing (including common bacterial, mycobacterial and fungal procedures) did not detect any pathogen. Hemogram and biochemical examination of blood were normal. Vancomycin and ceftriaxone were prescribed for 14 days, dexamethasone, $16 \mathrm{mg} /$ day, for 10 days, followed by 15 days of prednisone weaning. She was discharged with partial improvement of headache, without vomiting and presenting normal CSF. After 3 weeks, the headache intensified and vomiting returned. Prednisone $80 \mathrm{mg} /$ day, for 7 days, followed by 30 days of weaning was prescribed, resulting in mild improvement of headache, but with persistent vomiting and return of rotational vertigo. Therefore, cinnarizine, esomeprazole, bromopride and paracetamol/codeine were prescribed. As no relief was obtained after 30 days, the patient was re-hospitalized and CSF analysis revealed: 245 cells $/ \mathrm{mm}^{3}$, $88 \%$ of lymphomonocytes, $23 \mathrm{mg} / \mathrm{dL}$ of glucose levels and proteins of $324 \mathrm{mg} / \mathrm{dL}$. Microbiological cultures for bacteria and fungi were negative. Hemogram and biochemical examination of blood were still normal. She was diagnosed again with occipital liquoric fistula and submitted to clinical treatment. She was under the same antimicrobial and corticoid regimen of the last hospitalization and was discharged with mild headache. Dexamethasone $16 \mathrm{mg} /$ day, for 10 days, followed by 30 days of weaning with prednisone was prescribed. At that moment, the CSF still had 68 cells $/ \mathrm{mm}^{3}$, with $100 \%$ of lymphomonocytes, $56 \mathrm{mg} / \mathrm{dL}$ of glucose levels and $78 \mathrm{mg} / \mathrm{dL}$ of proteins. Prednisone was prescribed for 30 days.

When the corticoid was discontinued, headache worsened and vomiting returned. After 5 months of the onset of the disease, a new computed tomography (CT) scan of the skull showed a CSF fistula on the same topography. She was hospitalized and submitted to a surgery to correct the fistula. She had leukocytosis on admission (16,000 leukocytes $/ \mathrm{mm}^{3}$, with $88 \%$ segmented cells) and CSF analysis 
showed 280 cells $/ \mathrm{mm}^{3}$, being $88 \%$ of lymphomonocytes cells, $12 \mathrm{mg} / \mathrm{dL}$ of glucose levels and $312 \mathrm{mg} / \mathrm{dL}$ of proteins. Bacterial and fungal cultures were negative. Empirical treatment with vancomycin and cefepime was introduced for 21 days and dexamethasone $16 \mathrm{mg} /$ day for 10 days, followed by 20 days of weaning with prednisone. As the headache worsened, she was again hospitalized and submitted to surgical correction of the fistula. New CSF showed 184 cells, $63 \%$ of lymphomonocytes, $41 \mathrm{mg} / \mathrm{dL}$ of glucose levels and $285 \mathrm{mg} / \mathrm{dL}$ of proteins. Vancomycin, meropenem and dexamethasone, $10 \mathrm{mg} /$ day were initiated. On the 5th day of treatment, headache remained intense and frequent vomiting. A new CT suggested hydrocephalus and the patient was submitted to a ventriculoperitoneal (VP) shunt. After 3 days of VP, the patient continued to present with vomiting and leukocytosis and the CSF pressure was above $300 \mathrm{mmH}_{2} \mathrm{O}$. She was admitted to the intensive care unit. A magnetic resonance imaging (MRI) of the skull suggested meningeal thickening, spinal cord compression at the level of C5-C6 and the alteration of the CSF signal was compatible with viral or fungal disease (Fig. 1). The initial suspicion was cryptococcosis. Liposomal amphotericin B (300 mg/day) and acyclovir therapy were empirically initiated. After several

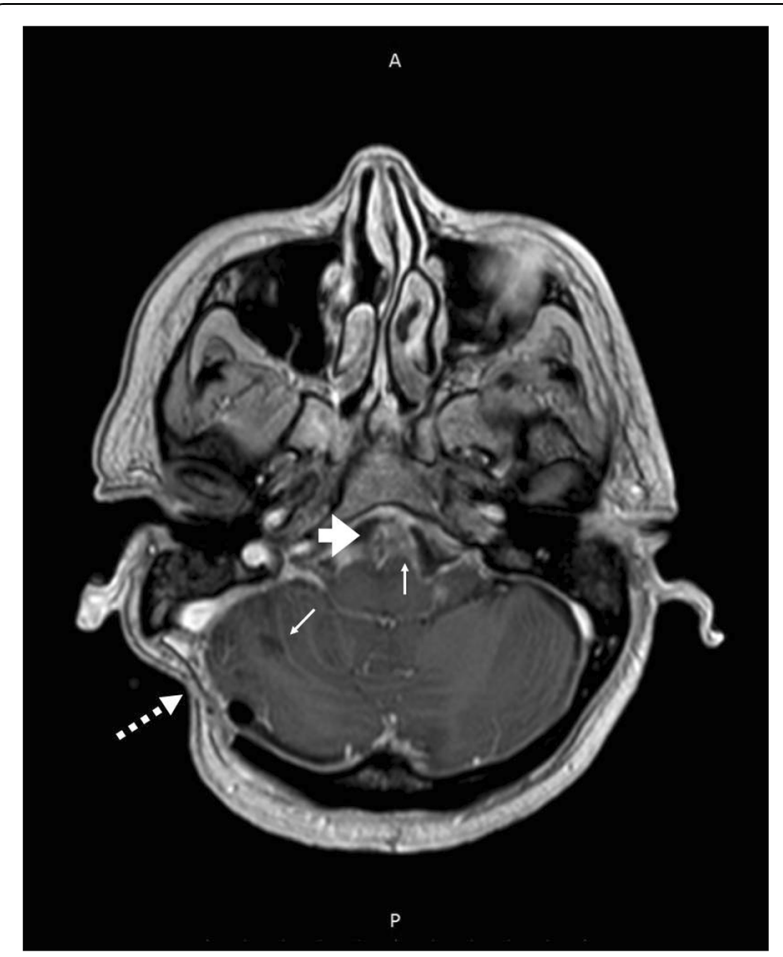

Fig. 1 Axial Magnetic Resonance Imaging (MRI) at the posterior fossa level, showing extensive leptomeningeal enhancement near the anterior bulb contour and cerebellar folds (thin arrows). Heterogeneous material with enhancement near the pre-pontine cistern (thick arrow). Note the signs of surgical manipulation of the extra-cranial soft parts in the right occipital region (dashed arrow) invasive procedures, broad spectrum antibiotics and corticosteroids, CSF culture showed growth of Trichosporon spp. After 2 weeks, another Trichosporon CSF positive culture was obtained. As there was progressive worsening of the clinical condition, voriconazole ( $200 \mathrm{mg} /$ every $12 \mathrm{~h}$ ) was added to the previous prescription. On the 20th day of hospitalization, the patient died (Table 1).

\section{Culturing procedures and molecular identification of the pathogen}

The CSF was centrifuged at $2500 \mathrm{rpm}$ for $10 \mathrm{~min}$ and the sediment was used for direct examination and culture. Direct examination was performed with India ink which revealed no encapsulated blastoconidia. The sediment of 2 CSF samples collected at different days (14th and 28th of April, 2015) were plated on Sabouraud Dextrose Agar at room temperature $\left(28+2{ }^{\circ} \mathrm{C}\right)$ and yielded positive yeast cultures after $72 \mathrm{~h}$ of incubation. The two cultures were send to the Medical and Molecular Mycology Laboratory, Clinical and Toxicological Analyses Department, Federal University of Rio Grande do Norte State for further molecular identification. Of note, both colonies had a mucoid aspect. Besides, because Cryptococcus spp. are the main etiological fungal agents obtained from meningitis, that was the first suspicion. Yeast isolates from original cultures were plated onto CHROMagar Candida (CHROMagar Microbiology, Paris, France) and corn meal-Tween 80 (to induce sporulation). Surprisingly, both isolates had a macroscopic wrinkled appearance, were able to produce arthroconidia, as revealed by their micromorphology, and to hydrolyze urea (Fig. 2a to d). Therefore, they were considered to belong to the genus Trichosporon and named HGT198 and HGT914, respectively. Both strains were further identified by molecular techniques.

\section{Molecular identification}

A single colony of each strain was used for DNA extraction with PrepMan Ultra sample preparation reagent (Applied Biosystems, Foster City, CA) according to the manufacturer's instructions. Genomic DNA concentration and purity were checked with a NanoDrop instrument (Thermo Scientific; Amersham Pharmacia Biotech, Wilmington, DE, USA). Both strains were further identified by a molecular method as detailed elsewhere [29]. DNA amplification was obtained by using the primer pair TRF ( 5 '-AGAGGCCTA CCATGGTATCA-3') and TRR (5'-TAAGACCCAATAGA GCCCTA-3') [26]. Nucleotide sequences were submitted for BLAST analysis at the NCBI site (http://www.ncbi.nlm.nih.gov) for species identification. Only sequences deposited in GenBank showing high similarities with our query sequences and an $E$-value of lower than $10^{-5}$ were used in this study. BLAST searches showed the best match with $T$. inkin (FJ153608.1), 100\% identity (619 of 619 bp without gap sites) for both strains (HGT198 and HGT914). IGS1 
Table 1 Timeline of exposition to multiple risk conditions of a patient submitted to an acoustic neuroma surgery and further developed meningitis in Natal city, Rio Grande do Norte State, Northeast Brazil

\begin{tabular}{|c|c|c|c|c|c|c|c|c|c|c|}
\hline $\begin{array}{l}\text { Period } \\
\text { of time }\end{array}$ & $\begin{array}{l}\text { Acoustic } \\
\text { neuroma } \\
\text { surgery }\end{array}$ & $\begin{array}{l}\text { Corticosteroids } \\
\text { usage }\end{array}$ & $\begin{array}{l}\text { Appearence of } \\
\text { the fistula }\end{array}$ & $\begin{array}{l}\text { Antibiotics } \\
\text { usage }\end{array}$ & $\begin{array}{l}\mathrm{CSF}^{\mathrm{a}} \text { analisys } \\
\text { performing }\end{array}$ & $\begin{array}{l}\text { Surgical fistula } \\
\text { correction }\end{array}$ & $V P^{b}$ shunt & $\begin{array}{l}\text { Antifungal } \\
\text { therapy }\end{array}$ & $\begin{array}{l}\text { Trichosporon } \\
\text { positive culture }\end{array}$ & Death \\
\hline Week 1 & $x$ & & & & & & & & & \\
\hline Week 6 & & $x$ & & & & & & & & \\
\hline Week 8 & & $x$ & $x$ & $x$ & $x$ & & & & & \\
\hline Week 9 & & $x$ & & $x$ & & & & & & \\
\hline Week 13 & & $x$ & & & & & & & & \\
\hline Week 17 & & $x$ & $x$ & $x$ & $x$ & & & & & \\
\hline Week 18 & & $x$ & & $x$ & & & & & & \\
\hline Week 19 & & $x$ & & $x$ & & & & & & \\
\hline Week 20 & & $x$ & $x$ & $x$ & $x$ & $x$ & & & & \\
\hline Week 21 & & $x$ & & $x$ & & & & & & \\
\hline Week 22 & & $x$ & & $x$ & & & & & & \\
\hline Week 23 & & $x$ & & $x$ & $x$ & $x$ & $x$ & $x$ & $x$ & \\
\hline Week 24 & & $x$ & & $x$ & & & & $x$ & & \\
\hline Week 25 & & & & & & & & $x$ & $x$ & \\
\hline Week 26 & & & & & & & & $x$ & & $x$ \\
\hline
\end{tabular}

${ }^{\mathrm{a}} \mathrm{CSF}$ Cerebrospinal fluid, ${ }^{\mathrm{b}} V P$ Ventriculoperitoneal

rDNA sequences of these strains have been deposited in GenBank under accession numbers KY807052 and KY807053, respectively. Of note, both strains were considered of $100 \%$ identity, after blastn analysis (all the $641 \mathrm{bp}$ compared among them), with an $E$-value of 0 and no gaps found between the two IGS1 rDNA sequences.

\section{Characterization of virulence factors and in vitro antifungal susceptibility}

Strains HGT198 and HGT914 were evaluated according to their ability to adhere to human buccal epithelial cells, biofilm formation, hemolysins and phospholipase production by using the methods described by Zuza-Alves [30]. DNAse production was determined according to Montoya [16].
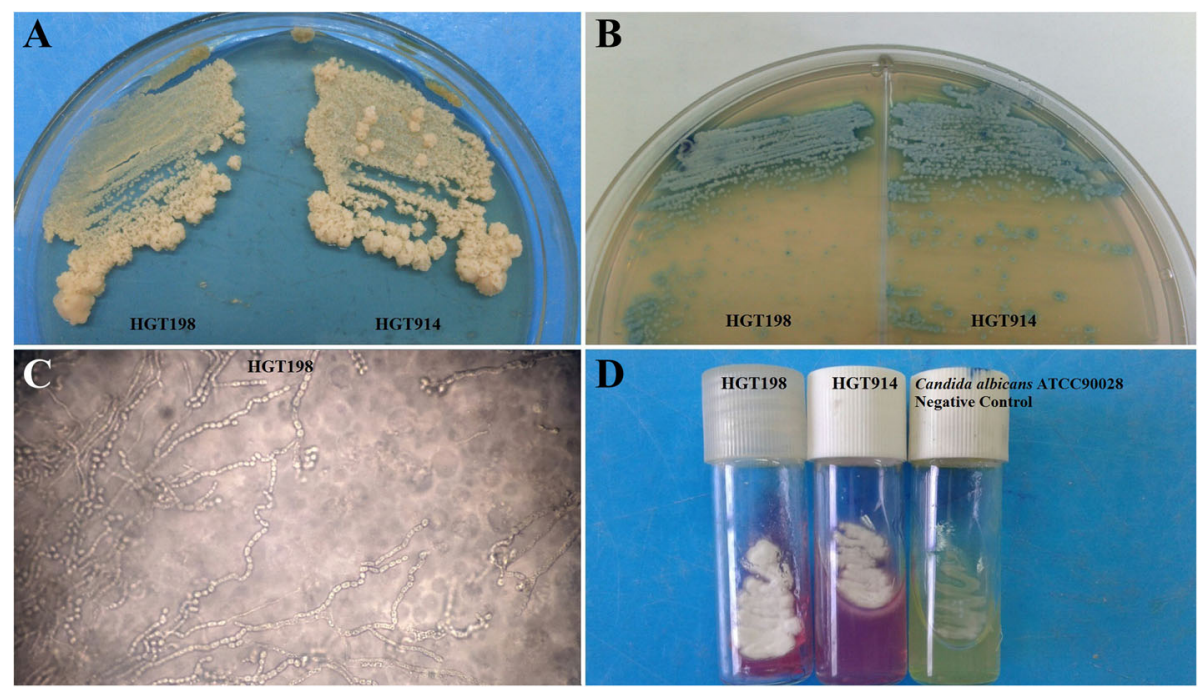

Fig. 2 a Cream-colored, dull, wrinkled cerebriform colonies, after $48 \mathrm{~h}$ of incubation at $30^{\circ} \mathrm{C}$ on Sabouraud dextrose agar. b Colonies with typical "dirty" grey-blue color on CHROMagar Candida medium after $72 \mathrm{~h}$ of incubation at $35^{\circ} \mathrm{C}$. c Micromorphological aspects after incubation in cornmeal agar containing Tween 80 for $72 \mathrm{~h}$ at $30^{\circ} \mathrm{C}$, showing long true hyphae e artroconidia. d Urease test of yeast cells grown in Cristensen's urea Agar containing phenol red, showing positive results after incubation at $30^{\circ} \mathrm{C}$ for $72 \mathrm{~h}$ 
Both strains did not produce phospholipase or DNAse. However, they showed high biofilm formation capability as compared to C. albicans ATCC90028 and T. asahii CBS2630 and similar levels of hemolysin production of the two reference strains. In addition, they were able to adhere to epithelial cells to the same extension of $T$. asahii reference strain (Table 2).

Both strains were tested against fluconazole, itraconazole and amphotericin Bby using the CLSI protocol [31-33]. As illustrated on Table 3, they exhibited very low MIC values against all antifungal drugs tested.

\section{Discussion and conclusions}

Trichosporon species are present in the environment and may belong to the human microbiota butmay associated with both superficial and deep infections $[1,18]$. Infections associated with CNS due Trichosporon are rare in immunocompromised patients and extremely rare in immunocompetent patients [20].

The number of cases of invasive trichosporonosis reported worldwide may be still considered restrict once a limited number of publications may be found in the literature [27]. A recent epidemiological study conducted by De Almeida Júnior et al. [27] reviewing global cases of invasive trichosporonosis retrieved from PubMed from 1994 and 2015 only found a total of 203 cases of invasive trichosporonosis, where T. asahii accounted for 95 (47.6\%) of all cases [27].

The first case of SNC infection due Trichosporon was described by Watson and Kallichurum in 1970 [25] in a 39-year-old African woman diagnosed with underlying bronchial adenocarcinoma and brain abscess due T. cutaneum [25]. It is important to mention that no molecular techniques were available at this time. Therefore, this could have led to an unreliable species identification. Since then, only other few case reports of Trichosporon meningitis have been published in the literature, but none of them was due to T. inkin (Table 4).

The geographic distribution of invasive trichosporonosis with CNS complications is higher in Asia (seven cases) [2, 18-22, 24]. There are cases described in Europe [23],
Africa [25] and Central America (one case each) [4]. Clinical series with patients' demographic data and underlying conditions may be found in Table 4.

There is only a single study reporting Trichosporon meningitis in an immunocompetent patient [22]. In this study, Rastoji et al. [22] reported a case of invasive trichosporonosis with CNS complications in a 18-years-old male, who presented fever, chills and rigor associated with headache, nausea, vomiting and altered sensorium. T. asahii was isolated from CSF and sputum of this patient [22].

Several clinical conditions are considered to be risk factors for invasive trichosporonosis including the history of intensive chemotherapy, high dose of corticosteroids, burns, neutropenia, broad spectrum antibiotics usage and hematological malignancies $[8,20,27]$. In fact, the patient described in this study was previously immunocompetent but further submitted to long periods of corticosteroids and broad-spectrum antibiotics, besides suffering the invasive medical procedure to remove an acoustic neuroma. Of note, the CSF fistula probably had an important role for local Trichosporon contamination. In addition, the fact that she had a parrot could have led to yeasts skin colonization, once these birds may harbor Trichosporon in their gastrointestinal tract [34]. A limitation of our study is that we did not perform her parrot's droppings culture, trying to isolate Trichosporon and further checked with molecular techniques to determine the probable source of infection.

Our isolates were as able to adhere to epithelial cells as $T$. asahii CBS2630 that is considered the most virulent and frequently isolated species of the genus Trichosporon, as demonstrated by virulence studies with Galleria mellonella and murine models of systemic infection [35]. Of note, all Trichosporon isolates were less adherent than Candida albicans ATCC90028. This was expected, because C. albicans is widely recognized as the more adherent Candida species [36], but it was used as a reference strain for adhesion assay.

Both isolates (HGT198 and HGT914) had stronger hemolytic activities than reference strain T. asahii CBS2630. Our isolates were considered highly hemolytic according

Table 2 Evaluation of attributes of virulence factors in vitro of Trichosporon inkin isolates HGT198 and HGT914 obtained from a patient submitted to an acoustic neuroma surgery and further developed meningitis in Natal city, Rio Grande do Norte State, Northeast Brazil

\begin{tabular}{llll}
\hline & $N^{0}$ of T. inkin cells adhered to 150 HBEC & Hemolytic index (HI) & Biofilm formation $\left(\mathrm{OD}_{595 \mathrm{~nm})}\right.$ \\
\hline Candida albicans ATCC90028 & $179.8 \pm 2.05$ & $0.63 \pm 0.01$ & $0.24 \pm 0.03$ \\
Trichosporon asahii CBS2630 & $34.3 \pm 1.70$ & $0.74 \pm 0.01$ & $0.40 \pm 0.01$ \\
Trichosporon inkin HGT198 & $36.7 \pm 1.50^{\mathrm{a}}$ & $0.68 \pm 0.01^{\mathrm{a} ; \mathrm{b}, \mathrm{c}}$ & $0.77 \pm 0.05^{\mathrm{a} ; \mathrm{b}, \mathrm{c}}$ \\
Trichosporon inkin HGT914 & $37.3 \pm 1.50^{\mathrm{a}}$ & $0.56 \pm 0.01^{\mathrm{a} ; \mathrm{b}, \mathrm{c}}$ & $1.04 \pm 0.01^{\mathrm{a} ; \mathrm{b}, \mathrm{c}}$ \\
\hline
\end{tabular}


Table 3 Determination of antifungal susceptibility testing of Trichosporon inkin isolates HGT198 and HGT914 obtained from a patient submitted to an acoustic neuroma surgery and further developed meningitis in Natal city, Rio Grande do Norte State, Northeast Brazil

\begin{tabular}{llll}
\hline Strain & Fluconazole $(24 \mathrm{~h})$ & Itraconazole $(48 \mathrm{~h})$ & Amphotericin B $(48 \mathrm{~h})$ \\
\hline Candida parapsilosis ATCC 22019 & $1 \mu \mathrm{g} / \mathrm{mL}$ & $\mathrm{NT}$ & $\mathrm{NT}$ \\
Candida krusei ATCC6258 & $16 \mu \mathrm{g} / \mathrm{mL}$ & $\mathrm{NT}$ & $\mathrm{NT}$ \\
Trichosporon inkin HGT-198 & $0.5 \mu \mathrm{g} / \mathrm{mL}$ & $0.062 \mu \mathrm{g} / \mathrm{mL}$ & $0.5 \mu \mathrm{g} / \mathrm{mL}$ \\
Trichosporon inkin HGT-914 & $0.5 \mu \mathrm{g} / \mathrm{mL}$ & $0.062 \mu \mathrm{g} / \mathrm{mL}$ & $0.5 \mu \mathrm{g} / \mathrm{mL}$ \\
\hline
\end{tabular}

with the criteria established by Montoya et al. [16]. These authors reported a single strain of $T$. asahii with strong hemolytic activity, while the other 38 isolates did not produce this enzyme. These finding reinforce virulence attributes properties of the isolates from the present study that may have influenced clinical outcome.

Biofilm formation by microorganisms has gained attention within clinical practice because of its ability to increase mortality in patients with systemic infections by yeasts [37]. Studies on biofilm formation in Trichosporon have increased in recent years, since this yeast has been considered the second most common etiological agent of systemic infection in patients with hematological malignancies [38]. In the presence of biofilm, structured microbial communities remain embedded within an extracellular polymeric substance, where Trichosporon spp. show significantly greater resistance to antifungals, with MICs ranging from 128 to $1.024 \mu \mathrm{g} / \mathrm{mL}$ for Amphotericin B and $512-1.024 \mu \mathrm{g} / \mathrm{mL}$ for Fluconazole,
Itraconazole, and Voriconazole [38]. Our isolates showed an optical density of $595 \mathrm{~nm}$ (which reflects biofilm biomass stained by crystal violet) at least two-fold higher than the readings found for $T$. asahii CBS6030. Of note, there is a trend of increased virulence attributes expression over time when both strains isolated 2 weeks apart were compared (Table 1). This phenomenon is observed for both hemolysins and biofilm production. This may reflect strain adaptation to the host in the progress of infection.

Our strains were not resistant to any of the antifungal drugs tested. In addition, MICs obtained from T. inkin HGT198 and HGT914 did not increase over time. This observation indicates that probably there was not induced antifungal resistance for the strains recovered within 2 weeks of difference. It is important to emphasize that antifungal susceptibility testing was only possible to be performed after patient's death and was not used to drive antifungal therapy.

Table 4 Systematic review of Trichosporonosis meningitis cases published in the literature from to 1970 to 2018

\begin{tabular}{|c|c|c|c|c|c|c|}
\hline Country & Sex/Age & Diagnosis/Underlying diseases & Species isolated & Clinical Sample & Treatment/outcome & Year/Reference \\
\hline$\overline{\text { Brazil }}$ & & & Trichosporon inkin & CSF & & $\overline{\text { Present study }}$ \\
\hline Singapore & $\mathrm{F} / 50$ & $\begin{array}{l}\text { Disseminated trichosporonosis/ } \\
\text { Aplastic Anemia }\end{array}$ & T. asahii & CSF, Blood & $\begin{array}{l}\text { AMB, VOR, ITR, POS/ } \\
\text { Survived }\end{array}$ & $2016[24]$ \\
\hline India & $M / 18$ & $\begin{array}{l}\text { Chronic meningo-ventriculitis } \\
\text { and intraventricular fungal } \\
\text { ball/immunocompetent }\end{array}$ & T. asahii & $\begin{array}{l}\text { Intraventricular } \\
\text { biopsy and CSF }\end{array}$ & AMB/died & 2015 [20] \\
\hline Iran & $M / 34$ & $\begin{array}{l}\text { Brain abscess/ autoimmune } \\
\text { hepatitis, hypothyroidism }\end{array}$ & T. asahii & Brain abscess & $\begin{array}{l}\text { Surgical resection, } \\
\text { AMB and ITC/ survived }\end{array}$ & 2012 [18] \\
\hline India & $\mathrm{NI}$ & $\begin{array}{l}\text { Meningitis/Acquired } \\
\text { Immunodeficiency } \\
\text { Syndrome (AIDS) }\end{array}$ & Trichosporon sp. & CSF & AMB, FLU, survived & 2012 [19] \\
\hline Jamaica & $\mathrm{F} / 44$ & $\begin{array}{l}\text { Meningitis and cerebral } \\
\text { abscess/diabetes, burns }\end{array}$ & T. asahii & $\begin{array}{l}\text { Facial wounds, } \\
\text { sputum, and a } \\
\text { meningeal swab }\end{array}$ & None/died & $2011[4]$ \\
\hline Taiwan & $\mathrm{NI}$ & Meningitis/NI & T. montevideense & CSF & $\mathrm{Nl}$ & 2009 [2] \\
\hline India & $M / 18$ & $\begin{array}{l}\text { Disseminated trichosporonosis/ } \\
\text { Imunnocompetent }\end{array}$ & T. asahii & CSF & FLU/survived & 2007 [22] \\
\hline India & $F / 36$ & $\begin{array}{l}\text { Chronic meningitis/ Chronic } \\
\text { back pain after fall }\end{array}$ & T. beigelii & CSF & None/died & $1995[21]$ \\
\hline Belgium & $M / 15$ & $\begin{array}{l}\text { Meningitis/acute lymphocytic } \\
\text { leukaemia }\end{array}$ & T. beigelii & CSF & AMB, FC and FLU/died & $1990[23]$ \\
\hline South Africa & $F / 39$ & Brain abscess/adenocarcinoma & T. cutaneum & Brain lesions & None/died & $1970[25]$ \\
\hline
\end{tabular}


There are some limitations about the interpretations of MIC values in our Trichosporon isolates. First of all, there are still no breakpoints established from Clinical \& Laboratory Standards Institute (CLSI) and European Committee on Antimicrobial Susceptibility Testing (EUCAST) Antifungal Susceptibility testing to Trichosporon species [27], and second, there are no studies which determined MICs of T. inkin strains isolated from patients with meningoencephalitis.

Susceptibility testing to the antifungal drugs Amphotericin B, Itraconazole and Fluconazole were performed by Taj-Aldeen et al. [39] with three $T$. inkin clinical isolates obtained from urine and white piedra. MIC range was $1-4 \mu \mathrm{g} / \mathrm{mL}$ (Amphotericin B), 0.25-4 $\mu \mathrm{g} / \mathrm{mL}$ (Fluconazole) and $0.013-0.125 \mu \mathrm{g} / \mathrm{mL}$ (Itraconazole). $T$. inkin clinical isolates from bone, urine, skin, subcutaneous abscess, peritoneal liquid and blood susceptibility profiling was determined and MIC range was $0.06-1 \mu \mathrm{g}$ / $\mathrm{mL}$ (Amphotericin B), 1-32 $\mathrm{g} / \mathrm{mL}$ (Fluconazole) and $0.06-2 \mu \mathrm{g} / \mathrm{mL}$ (Itraconazole) [40]. In the present study, our T. inkin isolates had lower MIC values when compared with other publications $[39,40]$. We observed that Itraconazole exhibited better in vitro effect against T. inkin isolates compared to Fluconazole and Amphotericin $\mathrm{B}$ and this finding was also observed by other studies involving T. inkin [39, 40] and other Trichosporon species $[2,35]$.

In conclusion, we may say this is the first case report of meningitis caused by $T$. inkin reported in the literature. Our female previously healthy patient was under corticosteroids and antibiotics therapy for a few months. In addition, she was submitted to an invasive procedure to remove a left sided acoustic neuroma and further developed a cerebrospinal fistula. All those factors are consolidated risk conditions for the infection caused by $T$ inkin. The certainty of the invasive infection by $T$. inkin was based on the isolation of the pathogen along two different occasions together with brain images and cytological findings suggestive of meningitis. Both strains showed strong ability to express virulence factors in vitro. These findings together with patient's immunological status may have been crucial for the clinical outcome, because the strains were apparently not resistant to the antifungal drugs prescribed during her period of hospitalization. The physicians main suspicion was cryptococcal meningitis. Corroborating this idea, the strains obtained from CNF presented mucoid aspect in the primary isolation. However, the sending of these isolates to a reference Mycology center for accurate phenotypic and molecular identification revealed that the meningitis caused by Trichsporon inkin.

\section{Abbreviations}

ATCC: American Type Culture Collection; BLAST: Basic Local Alignment Search Tool; CBS: Centraalbureauvoor Schimmel cultures; CLSI: The Clinical \&
Laboratory Standards Institute; CNS: Central nervous system; CSF: Cerebrospinal fluid; CT: Computed tomography; Fig.: Figure; IGS1: Intergenic Spacer 1; MALDI-TOF: Matrix-Assisted Laser Desorption/ Ionization Time-of-Flight; MIC: Minimal Inhibitory Concentration; MRI: Magnetic Resonance Imaging; rpm: Revolutions per minute; VP: Ventriculoperitoneal

\section{Funding}

This work was supported by "Conselho Nacional de Desenvolvimento Científico e Tecnológico" (CNPq) Grant number: Edital Universal 484020/2013-7.

Availability of data and materials

The datasets used and/or analyzed during the current study are available from the corresponding author on reasonable request.

\section{Authors' contributions}

JJSA, TUGF and ALAP were the attending physicians for the patient and collected medical data of the patient. MFA performed microbiological analysis and in vitro experiments. ECF and ASAM performed strains molecular identification. ALC made a critical review of the manuscript and provided financial support and structure for molecular identification. WPSR performed experiments and wrote the paper. EPM designed and wrote the paper and critically analyzed medical data. GMC designed all the experiments, structured and wrote the paper and critically reviewed the manuscript. All authors read and approved the final manuscript.

\section{Ethics approval and consent to participate}

All clinical and demographic data of the patient were collected in accordance with the Local Research Ethics committee from the Liga NorteRiograndense Contra o Câncer Hospital, approved under number 042/042/2012.

\section{Consent for publication}

Written informed consent was obtained from the patient's family for publication of this case report and accompanying images. A copy of the written consent is available for review by the Editor of this journal.

\section{Competing interests}

The authors declare that they have no competing interests.

\section{Publisher's Note}

Springer Nature remains neutral with regard to jurisdictional claims in published maps and institutional affiliations.

\section{Author details}

${ }^{1}$ Departamento de Infectologia, Universidade Federal do Rio Grande do Norte, Natal, Rio Grande do Norte, Brazil. ${ }^{2}$ Centro de Ciências da Saúde, Laboratório de Micologia Médica e Molecular, Departamento de Análises Clínicas e Toxicológicas, Universidade Federal do Rio Grande do Norte, Rua Gal. Gustavo Cordeiro de Faria S/N, Petrópolis, Natal, Rio Grande do Norte, Brazil. 'aboratório Especial de Micologia, Disciplina de Infectologia, Universidade Federal de São Paulo, São Paulo, Brazil.

Received: 20 April 2018 Accepted: 24 August 2018

Published online: 18 September 2018

\section{References}

1. Colombo AL, Padovan AC, Chaves GM. Current knowledge of Trichosporon spp. and Trichosporonosis. Clin Microbiol Rev. 2011;24(4):682-700.

2. Ruan SY, Chien JY, Hsueh PR. Invasive trichosporonosis caused by Trichosporon asahii and other unusual Trichosporon species at a medical center in Taiwan. Clin Infect Dis. 2009;49(1):e11-7.

3. Chagas-Neto TC, Chaves GM, Colombo AL. Update on the genus Trichosporon. Mycopathologia. 2008;166(3):121-32.

4. Heslop OD, Nyi Nyi MP, Abbott SP, Rainford LE, Castle DM, Coard KC. Disseminated trichosporonosis in a burn patient: meningitis and cerebral abscess due to Trichosporon asahii. J Clin Microbiol. 2011;49(12):4405-8.

5. Silva WP, Lemos VL, Milan EP, Chaves GM. Species distribution and phospholipase activity of fungi isolated from children with dermatomycosis from child day care units in Natal, Brazil. J Eur Acad Dermatol Venereol. 2013;27(10):1319-21. 
6. Magalhaes AR, Nishikawa MM, Mondino SS, Macedo HW, Rocha EM, Baptista AR. Trichosporon isolation from human ungueal infections: is there a pathogenic role? An Bras Dermatol. 2016;91(2):173-9.

7. Silva-Rocha WP, de Azevedo MF, Chaves GM. Epidemiology and funga species distribution of superficial mycoses in Northeast Brazil. J Mycol Med. 2017;27(1):57-64.

8. Duarte-Oliveira C, Rodrigues F, Goncalves SM, Goldman GH, Carvalho A, Cunha C. The cell biology of the Trichosporon-host interaction. Front Cell Infect Microbiol. 2017;7:118.

9. Almeida Junior JN, Song AT, Campos SV, Strabelli TM, Del Negro GM, Figueiredo DS, Motta AL, Rossi F, Guitard J, Benard G, et al. Invasive Trichosporon infection in solid organ transplant patients: a report of two cases identified using IGS1 ribosomal DNA sequencing and a review of the literature. Transpl Infect Dis. 2014;16(1):135-40

10. Arendrup MC, Boekhout T, Akova M, Meis JF, Cornely OA, Lortholary O. ESCMID and ECMM joint clinical guidelines for the diagnosis and management of rare invasive yeast infections. Clin Microbiol Infect. 2014;20(Suppl 3):76-98.

11. Macedo DP, de Oliveira NT, da Silva VK, de Almeida Farias AM, de Lima Neto RG, Wilheim AB, de Oliveira PC, Pedi N, de Andrade SL, Neves RP. Trichosporon inkin esophagitis: an uncommon disease in a patient with pulmonary cancer. Mycopathologia. 2011;171(4):279-83.

12. Moretti-Branchini ML, Fukushima $K$, Schreiber AZ, Nishimura $K$, Papaiordanou PM, Trabasso P, Tanaka R, Miyaji M. Trichosporon species infection in bone marrow transplanted patients. Diagn Microbiol Infect Dis. 2001;39(3):161-4.

13. Nobrega de Almeida Junior J, Buccheri de Oliveira R, Duarte A, Lopes Motta A, Rossi F, Sachiko Yamamoto de Figueiredo D, Barbaro Del Negro GM, Aoki V, Wakisaka Maruta C, Giuli Santi C, et al. Trichosporon inkin as an emergent pathogen in patients with severe pemphigus. JAMA Dermatol. 2015;151(6):642-5.

14. Wynne SM, Kwon-Chung KJ, Shea YR, Filie AC, Varma A, Lupo P, Holland SM. Invasive infection with Trichosporon inkin in 2 siblings with chronic granulomatous disease. J Allergy Clin Immunol. 2004;114(6):1418-24.

15. Taguti Irie MM, Lopes Consolaro ME, Aparecida Guedes T, Donatti L, Valeria Patussi E, Estivalet Svidzinski TI. A simplified technique for evaluating the adherence of yeasts to human vaginal epithelial cells. J Clin Lab Anal. 2006;20(5):195-203.

16. Montoya AM, Sanchez Gonzalez A, Palma-Nicolas JP, Gomez-Trevino A, Gonzalez JG, Gonzalez GM. Genotyping, extracellular compounds, and antifungal susceptibility testing of Trichosporon asahii isolated from Mexican patients. Med Mycol. 2015;53(5):505-11.

17. de Aguiar Cordeiro R, Serpa R, Flavia Uchoa Alexandre C, de Farias Marques FJ, Vladia Silva de Melo C, da Silva Franco J, Jose de Jesus Evangelista A, Pires de Camargo Z, Samia Nogueira Brilhante R, Fabio Gadelha Rocha M, et al. Trichosporon inkin biofilms produce extracellular proteases and exhibit resistance to antifungals. J Med Microbiol. 2015;64(11):1277-86.

18. Basiri K, Meidani M, Rezaie F, Soheilnader S, Fatehi F. A rare case of Trichosporon brain abscess, successfully treated with surgical excision and antifungal agents. Neurol Neurochir Pol. 2012;46(1):92-5.

19. Badiye A, Patnaik M, Deshpande A, Rajendran C, Chandrashekara KV. Think fungus NOT just a crypto-meningitis in AIDS! J Assoc Physicians India. 2012;60:21-4.

20. Kumar A, Udayakumaran S, Babu R, Rajamma BM, Prakash A, Panikar D, Karim S, Chowdhary A. Trichosporon asahii infection presenting as chronic meningo-ventriculitis and intra ventricular fungal ball: a case report and literature review. Mycoses. 2015;58(2):99-103.

21. Mathews MS, Prabhakar S. Chronic meningitis caused by Trichosporon beigelii in India. Mycoses. 1995;38(3-4):125-6.

22. Rastogi VL, Nirwan PS. Invasive trichosporonosis due to Trichosporon asahii in a non-immunocompromised host: a rare case report. Indian J Med Microbiol. 2007;25(1):59-61

23. Surmont I, Vergauwen B, Marcelis L, Verbist L, Verhoef G, Boogaerts M. First report of chronic meningitis caused by Trichosporon beigelii. Eur J Clin Microbiol Infect Dis. 1990;9(3):226-9.

24. Thien SY, Chung SJ, Tan AL, Hwang WY, Tan BH, Tan TT. Recurrent trichosporonosis with central nervous system involvement in an allogeneic hematopoietic stem cell transplant recipient. Transpl Infect Dis. 2016;18(5):768-72

25. Watson KC, Kallichurum S. Brain abscess due to Trichosporon cutaneum. J Med Microbiol. 1970;3(1):191-3.
26. Sugita T, Nakajima M, Ikeda R, Matsushima T, Shinoda T. Sequence analysis of the ribosomal DNA intergenic spacer 1 regions of Trichosporon species. J Clin Microbiol. 2002;40(5):1826-30.

27. de Almeida Junior JN, Hennequin C. Invasive Trichosporon infection: a systematic review on a re-emerging fungal pathogen. Front Microbiol. 2016;7:1629.

28. Hrabovsky V, Takacova V, Schreterova E, Pastvova L, Hrabovska Z, Curova K, Siegfried L. Distribution and antifungal susceptibility of yeasts isolates from intensive care unit patients. Folia Microbiol (Praha). 2017;62(6):525-30.

29. Chagas-Neto TC, Chaves GM, Melo AS, Colombo AL. Bloodstream infections due to Trichosporon spp.: species distribution, Trichosporon asahii genotypes determined on the basis of ribosomal DNA intergenic spacer 1 sequencing, and antifungal susceptibility testing. J Clin Microbiol. 2009;47(4):1074-81.

30. Zuza-Alves DL, de Medeiros SS, de Souza LB, Silva-Rocha WP, Francisco EC, de Araujo MC, Lima-Neto RG, Neves RP, Melo AS, Chaves GM. Evaluation of virulence factors in vitro, resistance to osmotic stress and antifungal susceptibility of Candida tropicalis isolated from the coastal environment of Northeast Brazil. Front Microbiol. 2016;7:1783.

31. CLSI: Clinical and Laboratory Standards Institute. Reference method for broth dilution antifungal susceptibility testing of yeasts; Approved standard-third edition (M27-A3). Wayne; 2008.

32. CLSI: Clinical and Laboratory Standards Institute. Reference method for broth dilution antifungal susceptibility testing of yeasts; Approved standard-third informational supplement (M27-S3). Wayne; 2008.

33. CLSI: Clinical and Laboratory Standards Institute. Reference method for broth dilution antifungal susceptibility testing of yeasts; Approved standard —-third informational supplement (M27-S4). Wayne; 2012.

34. Middelhoven WJ, Scorzetti G, Fell JW. Systematics of the anamorphic basidiomycetous yeast genus Trichosporon Behrend with the description of five novel species: Trichosporon vadense, T. smithiae, T. dehoogii, T. scarabaeorum and T. gamsii. Int J Syst Evol Microbiol. 2004;54(Pt 3):975-86.

35. Marine M, Bom VL, de Castro PA, Winkelstroter LK, Ramalho LN, Brown NA, Goldman $\mathrm{GH}$. The development of animal infection models and antifungal efficacy assays against clinical isolates of Trichosporon asahii, T. asteroides and T. inkin. Virulence. 2015;6(5):476-86.

36. Chaves GM, Diniz MG, da Silva-Rocha WP, de Souza LB, Gondim LA, Ferreira MA, Svidzinski TI, Milan EP. Species distribution and virulence factors of Candida spp. isolated from the oral cavity of kidney transplant recipients in Brazil. Mycopathologia. 2013;175(3-4):255-63.

37. Tumbarello M, Fiori $B$, Trecarichi EM, Posteraro P, Losito AR, De Luca A, Sanguinetti M, Fadda G, Cauda R, Posteraro B. Risk factors and outcomes of candidemia caused by biofilm-forming isolates in a tertiary care hospital. PLoS One. 2012;7(3):e33705.

38. Liao Y, Zhao H, Lu X, Yang S, Zhou J, Yang R. Efficacy of ethanol against Trichosporon asahii biofilm in vitro. Med Mycol. 2015;53(4):396-404.

39. Taj-Aldeen SJ, Al-Ansari N, El Shafei S, Meis JF, Curfs-Breuker I, Theelen B, Boekhout T. Molecular identification and susceptibility of Trichosporon species isolated from clinical specimens in Qatar: isolation of Trichosporon dohaense Taj-Aldeen, Meis \& Boekhout sp. nov. J Clin Microbiol. 2009:47(6):1791-9.

40. Ramos JM, Cuenca-Estrella M, Gutierrez F, Elia M, Rodriguez-Tudela JL. Clinical case of endocarditis due to Trichosporon inkin and antifungal susceptibility profile of the organism. J Clin Microbiol. 2004;42(5):2341-4.
Ready to submit your research? Choose BMC and benefit from:
- fast, convenient online submission
- thorough peer review by experienced researchers in your field
- rapid publication on acceptance
- support for research data, including large and complex data types
- gold Open Access which fosters wider collaboration and increased citations
- maximum visibility for your research: over $100 \mathrm{M}$ website views per year
At BMC, research is always in progress.
Learn more biomedcentral.com/submissions 